\title{
Alexander G. Roumiantsev - Anniversary (70 years)
}

\author{
Professor Boris V. Afanasyev, Editor-in Chief “Cellular Therapy and Transplantation”, Director of R. Gorbacheva Memorial \\ Institute of Children Oncology, Hematology and Transplantation, St. Petersburg
}

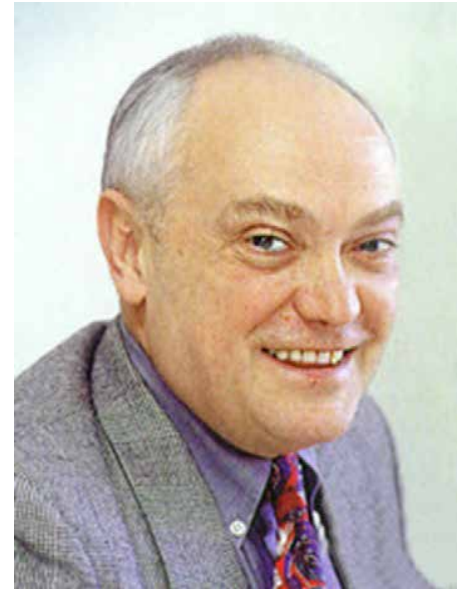

This year we are celebrating the $70^{\text {th }}$ Anniversary of Prof. Dr.Med. Alexander G. Roumiantsev, one of the most outstanding scientists, a hematologist-pediatrician of Russia, a person of the highest professional qualities and humanity. His achievements in the area are well known not only in Russia, but also worldwide. He is the President of National Association of Pediatric Oncologists and Hematologists, Chief Pediatrician of the Moscow Health Care Department, General Director of D.Rogacheva National Scientific and Practical Center of Pediatric Hematology and Oncology. A. G. Roumiantsev headed The Chair of Oncology, Hematology and Radiation Therapy at the Pediatric Faculty of N. Pirogov Russian National Research Medical University for many years.
Alexander Grigoryevich graduated with honors from the Pediatric Faculty at the $2^{\text {nd }}$ N. I. Pirogov Moscow State Medical Institute in 1971, and, in subsequent times, he was within the walls of the $2^{\text {nd }}$ MOLGMI (since 1991 - Russian State Medical University, since 2011 - N. I. Pirogov Russian National Research Medical University). Over these years, A. G. Roumiantsev approved himself a highly qualified specialist in pediatrics, hematology/immunology, a skilled scientist and university professor. A gifted teacher who authored and co-authored several basic educational programs in children diseases, polyclinic pediatrics, pediatric hematology/oncology, immunology/allergology, transfusion medicine, scientific editor of some basic textbooks and teaching media in pediatrics, pediatric hematology and immunology. In 1991, A. Roumiantsev was among founders of a tutorial course in pediatric Hematology/Oncology aimed for clinical teaching of pediatricians in this field of medicine. In the same year, he has organized a new Research Institute of Children Hematology.

Roumiantsev authored more than 650 scientific works, including 45 monographs and manuals. As a researcher, he is known for his studies in the field of pediatric hematology and immunology, medical ecology, intensive and outpatient pediatrics, adolescent medicine and arrangements in public health, clinical physiology and pathophysiology of blood, regulation of hematopoiesis and immune response, pathogenesis and treatment of hereditary and acquired blood diseases in children. 
A. G. Roumiantsev is the author (co-author) of the original scientific concepts of the mechanism of adjuvant response in immunotherapy of leukemia, the biochemical limitation (tolerance) of the immune response in adjuvant immunotherapy of cancer patients. He carried out fundamental and applied research in the field of pathogenesis, diagnosis and treatment of anemia, hematopoietic depressions and leukemias. He organized a service of pediatric hematology/oncology in Russia, for the first time in the country cooperative groups were established to study the effectiveness of treatment of acute leukemia, malignant lymphomas in children,with arrangement of original protocols for the treatment of children with acute lymphoblastic leukemia, which received international admission. For the first time in Russia, molecular chips for the diagnosis of leukemia, a bank of umbilical precursor cells for unrelated transplants in pediatrics have been developed. Under the guidance of A. G. Roumiantsev for the first time in Russia, stem cell cord transplantation was performed for children with primary immunodeficiency, hematological and oncological diseases, and systemic studies of maternal and child microchimerism were organized.

A. G. Roumiantsev is the author of the guidelines on clinical pediatric transfusion and transplantation of hematopoietic cells in children, he and his co-workers have diagnosed and monitored cancer with the help of molecular probes of nucleic acids and their products in blood serum.

As to his most significant studies, one should mention the works concerning development of methods for diagnosing and treating blood diseases in children, functional methods for evaluating blood cells and bone marrow under normal and pathological conditions, immunotherapy of endotoxic shock, crush syndrome, clinical hematological and molecular genetic studies of environmental disasters. Under his direction, fundamental studies on the action of incorporated radionuclides upon the child's organism were performed based on his efforts during liquidation of the Chernobyl nuclear power plant accident.

Since 2015, A. G. Roumiantsev is the president of National Society of Pediatric Hematology and Oncology. He is heading the scientific platform "Oncology" of Russia Healthcare Ministry, Editor-in-Chief, or Editorial Board Member at several leading journals in pediatrics, hematology and oncology, member of the Russian Pharmaceutical Committee. For his scientific and pedagogical activities he was awarded honorary medal at the University of Montpellier (France, 1990), a number of national prizes and honorary diploma. In 1994, he was awarded the Russian Order of People's Friendship.

In December 1993 he was elected a corresponding member, in November 1995 - an academician of the Biomedicine Branch at the Russian Academy of Natural Sciences. In 2004, he was elected a corresponding member, in 2011 - Academician at the Russian Academy of Medical Sciences, in 2013 Academician at the Russian Academy of Sciences.

Despite his high academic positions, he is always the big-hearted person, optimistic, being of hopeful attitude toward friends and colleagues who wish him his usual creative activities in life and research, like as good health for long years. 


\title{
І Юбилей А. Г. Румянцева (70-летие)
}

\author{
Профессор Борис В. Афанасьев, главный редактор журнала «Клеточная Терапия и Трансплантация», Директор \\ НИИ детской онкологии, гематологии и трансплантологии им. Р. М. Горбачевой, Санкт-Петербург
}

В этом году мы отмечаем 70-летие профессора Александра Григорьевича Румянцева - одного из выдающихся российских ученых, специалиста в области детской онкогематологии, человека высочайших профессиональных качеств и гуманности. Его достижения широко известны не только в России, но и за рубежом. Он является президентом Национальной Ассоциации детских онкологов и гематологов, главным педиатром Московского департамента здравоохранения, генеральным директором Национального научно-практического центра детской гематологии и онкологии имени Димы Рогачева. В течение многих лет А. Г. Румянцев был главой кафедры онкологии, гематологии и радиационной терапии педиатрического факультета Российского национального исследовательского медицинского университета им. Н. И. Пирогова.

Александр Григорьевич в 1971 г. окончил с отличием педиатрический факультет Второго Московского ордена Ленина государственного медицинского института, и в последующие годы он работал в стенах этого ВУЗа (2-го МОЛГМИ, с 1991 г. - Российского государственного медицинского университета, с 2011 г. - Российского национального исследовательского медицинского университета им. Н. И. Пирогова). В тот период А. Г. Румянцев показал себя высококвалифицированным специалистом-педиатром, гематологом-иммунологом, ученым и преподавателем высшей школы. Талантливый педагог, автор и соавтор образовательных программ по лечению детских болезней, поликлинической педиатрии, педиатрической гематологии/онкологии, иммунологии/ аллергологии, трансфузиологии, научный редактор базовых руководств и учебных пособий по педиатрии, детской гематологии и иммунологии.
В 1991 г. А. Г. Румянцев был среди основателей учебного курса по педиатрической гематологии/онкологии, предназначенного для клинического обучения педиатров в области медицины. В том же году он организовал новый НИИ детской гематологии.

А. Г. Румянцев является автором более чем 650 научных трудов, в том числе - 45 монографий и руководств, как ученый он известен своими трудами в области детской гематологии и иммунологии, медицинской экологии, интенсивной и амбулаторной педиатрии, подростковой медицины и организации здравоохранения, кдинической физиологии и патофизиологии крови, регуляции гемопоэза и иммунного ответа, патогенеза и лечения наследственных и приобретенных болезней крови у детей.

Среди наиболее значимых - исследования, посвященные развитию методов диагноза и лечения болезней крови у детей, функциональных методов анализа клеток крови и костного мозга в норме и патологии, иммунотерапии эндотоксического шока, краш-синдрома, клинико-гематологические и молекулярно-генетические исследования экологических катастроф.

Под его руководством было выполнено фундаментальное исследование механизма действия инкорпорированных радионуклидов на детский организм в результате аварии на Чернобыльской АЭС.

А. Г. Румянцев является автором (соавтором) оригинальных научных концепций механизма адъювантного ответа в иммунотерапии лейкозов, биохимических ограничений (толерантности) иммунного ответа при адъювантной иммунотерапии онкологических больных. 
Он выполнял фундаментальные и прикладные исследования в области патогенеза, диагноза и лечения анемии, депрессий гемопоэза, и лейкозов. Он организовал службу педиатрической гематологии/онкологии в России, впервые в стране образовал кооперативные группы для исследований эффективности лечения лейкозов, злокачественных лимфом у детей, создания оригинальных протоколов лечения детей с острым лимфобластным лейкозом, который получил международное признание. Впервые в России были использованы молекулярные биочипы для диагностики лейкозов, а также банк стволовых пуповинных клеток для неродственных трансплантаций в педиатрии. Под руководством А. Г. Румянцева впервые в России была проведена трансплантация стволовых пуповинных клеток у детей по поводу первичного иммунодефицита, гематологических и онкологических заболеваний, а также были организованы системные исследования микрохимеризма у матери и ребенка. А. Г. Румянцев является автором руководств по клинической трансфузиологии и трансплантации гемопоэтических клеток детям. Вместе со своими сотрудниками он проводил ДНК-диагностику и мониторинг рака с помощью молекулярных ДНК-зондов, в том числе в сыворотке крови.

Среди наиболее значимых - исследования, посвященные развитию методов диагноза и лечения болезней крови у детей, функциональных методов анализа клеток крови и костного мозга в норме и патологии, иммунотерапии эндотоксического шока, краш-синдрома, клинико-гематологические и молекулярно-генетические исследования экологических катастроф.
Под его руководством было выполнено фундаментальное исследование механизма действия инкорпорированных радионуклидов на детский организм в результате аварии на Чернобыльской АЭС.

А. Г. Румянцев является президентом национального общества детских гематологов/онкологов России. Он является членом научного совета и руководителем научной платформы «Онкология» Минздрава РФ, главным редактором или членом редакционного совета ряда ведущих российских журналов в области педиатрии, гематологии и онкологии, членом Российского Фармацевтического комитета.

За свои научные и педагогические достижения А. Г. Румянцев награжден многими национальными премиями и почетными дипломами, в частности - медалью университета Монпелье (Франция) в 1990 г. В 1994 он был награжден российским орденом Дружбы Народов.

В декабре 1993 он был избран членом-корреспондентом, а в ноябре 1995 г. - академиком отделения биомедицины Академии естественных наук Российской Федерации. В 2004 г. избран членом-корреспондентом, в 2011 г. действительным членом Российской академии медицинских наук, в 2013 г. - академиком РАН.

Несмотря на свои академические заслуги и посты, Александр Григорьевич Румянцев с друзьями и коллегами всегда щедр, оптимистичен, полон юмора. Мы желаем А. Г. Румянцеву свойственной ему творческой активности в повседневной жизни и работе, а также доброго здоровья на долгие годы. 